\title{
A Case of Nasopalatine Duct Cyst with Cholesterol Granuloma in Maxillary Sinus
}

\author{
Ju Chang Kang ${ }^{1}$, Kyu Ha Shin ${ }^{1}$, Eun Mee Han ${ }^{2}$, and Sang Hyeon Ahn ${ }^{1}$ ii \\ ${ }^{1}$ Departments of Otorhinolaryngology-Head and Neck Surgery, ${ }^{2}$ Pathology, Bundang Jesaeng General Hospital, Daejin Medical Center, \\ Seongnam, Korea
}

비구개관낭과 동반된 상악동 내 콜레스테롤 육아종 1예

강주창 $^{1} \cdot$ 신규하 $^{1} \cdot$ 한은미 $^{2} \cdot$ 안상현 $^{1}$

대진의료재단 분당제생병원 이비인후-두경부외과, ${ }^{1}$ 병리과 ${ }^{2}$

\author{
Received August 30, 2019 \\ Revised November 15, 2019 \\ Accepted February 3, 2020 \\ Address for correspondence \\ Sang Hyeon Ahn, MD \\ Department of Otorhinolaryngology- \\ Head and Neck Surgery, \\ Bundang Jesaeng General Hospital, \\ Daejin Medical Center, \\ 20 Seohyeon-ro 180beon-gil, \\ Bundang-gu, Seongnam 13590, \\ Korea \\ Tel $+82-31-779-0258$ \\ Fax $+82-31-779-0265$ \\ E-mail medicent@dmc.or.kr
}

Nasopalatine duct cysts are the most common non-odontogenic cysts that occur in the maxilla Cholesterol granulomas, on the other hand, are commonly found in patients with chronic middle ear disease, but rarely occur in the paranasal sinuses. We report a rare case of a 30 -year-old woman who was treated for a nasopalatine duct cyst and cholesterol granuloma at the same time. The patient complained of sudden nasolabial pressure and right nasal obstruction from three weeks ago. A $3 \mathrm{~cm}$ sized cystic mass, diagnosed as a nasopalatine duct cyst, was observed in the maxilla and haziness of the right maxillary sinus suspected of chronic rhinosinusitis was detected by computerized tomography. Marsupialization of the nasopalatine duct cyst was performed through the endoscopic transnasal approach. Solid mass in the maxillary sinus, diagnosed with cholesterol granuloma by pathology after surgery, was completely removed by endoscopic sinus surgery. The patient was followed up for 18 months without any recurrence or complications. Korean J Otorhinolaryngol-Head Neck Surg 2020;63(11):528-32

\section{서 론}

비구개관낭(nasopalatine duct cyst)은 상악뼈에 발생하는 가장 흔한 비치성낭종으로 절치관(incisive canal)의 잔존 상 피세포가 자발적으로 증식하거나 감염 또는 외상으로 발생 하는 것으로 알려져 있다. ${ }^{1)}$ 전 인구의 $1 \%$ 에서 발견되며, 40 60대에 호발하고, 주로 무증상으로 영상검사에서 우연 히 발견되지만 감염이 동반될 경우 통증을 동반한 종창이나 농성 비루가 관찰된다. ${ }^{1,2)}$

반면에 콜레스테롤 육아종(cholesteroal granuloma)은 불 충분한 환기, 배액장애, 출혈로 인하여 적혈구가 분해된 후

This is an Open Access article distributed under the terms of the Creative Commons Attribution Non-Commercial License (https://creativecommons.org/licenses/by-nc/4.0) which permits unrestricted non-commercial use, distribution, and reproduction in any medium, provided the original work is properly cited.
콜레스테롤 결정이 침강되어 이물반응으로 형성된 육아조직 이다.) 폐, 복막, 유선 등의 다양한 신체 부위에서 발생하고, 두경부 영역에서는 중이(middle ear), 유돌봉소(mastoid air cell)에서 만성 염증과 관련되어 흔하게 발생하지만 비부비동 에서 발생하는 것은 드문 것으로 알려져 있다. ${ }^{4)}$

국내에 발표된 문헌에 따르면 10예의 비구개관낭의 치료가 보고되었고 ${ }^{5-9)}$ 비부비동에서 발견된 콜레스테롤 육아종의 경우는 19예가 보고되었지만) 두 질환이 동시에 진단되고 치 료된 증례는 없었다. 따라서 본 증례는 우측 상악동에서 발 견된 콜레스테롤 육아종을 동반한 비구개관낭을 진단하고 치료한 경험을 바탕으로 증례보고와 함께 문헌 고찰을 하고 자 한다. 


\section{증 례}

30세 여자 환자가 3주 전부터 갑자기 악화된 비구순(nasolabial fold) 부위 압박감과 우측 코막힘을 주소로 내원하 였다. 특이 내과적 과거력은 없었고 내원 2달 전 우측 편도궤 양으로 스테로이드 치료 후 호전되었으나 안면부위 및 코 증 상은 없었다. 비강 내시경 소견에서 좌측으로 비중격만곡이 관찰되었고, 낭종처럼 보이는 종물이 양측 비강저에 융기되 어 있었으며 우측 중비도에 비용종(nasal polyp)이 관찰되었 다(Fig. 1). 비부비동 컴퓨터전산화단층촬영(Computerized Tomography, CT) 영상에서 절치관(incisive canal)을 확장 하고 경구개(hard palate)의 중앙에서 우측으로 치우친 $3 \times 3$ $\times 2.5 \mathrm{~cm}$ 크기의 주변부 조영 증강이 잘 되는 경계가 분명한
저음영의 낭종이 관찰되었으며 일부 주변부 빼가 재형성된 소견을 보였다. 또한 우측 상악동과 사골동에는 비용종을 동반한 만성 비부비동염의 소견이 관찰되었다(Fig. 2).

$\mathrm{CT}$ 영상 소견을 바탕으로 우측 비용종을 동반한 만성 비 부비동염 및 비구개관낭으로 진단하고, 전신 마취 후 내시경 을 통한 우측 비부비동염 수술 및 비구개관낭에 대한 조대술 (marsupialization)을 계획하였다. 먼저 우측 중비도의 비용 종을 제거하였고 상악동 내부에 하얀색의 끈적한 콧물이 차 있어 흡인(suction)하여 제거 후 $1 \mathrm{~cm}$ 크기의 노란색 고형의 종물이 발견되어 조직검사를 시행하였다. 또한 우측 비강저 에 관찰되는 낭성 종물에 대해 경비강 접근을 통한 조대술 을 시행하였다. 낭종의 상연부에 수술용 칼로 $1 \mathrm{~cm}$ 절개를 시행하였을 때 짙은 갈색의 액체가 배출되었고 조직 일부를
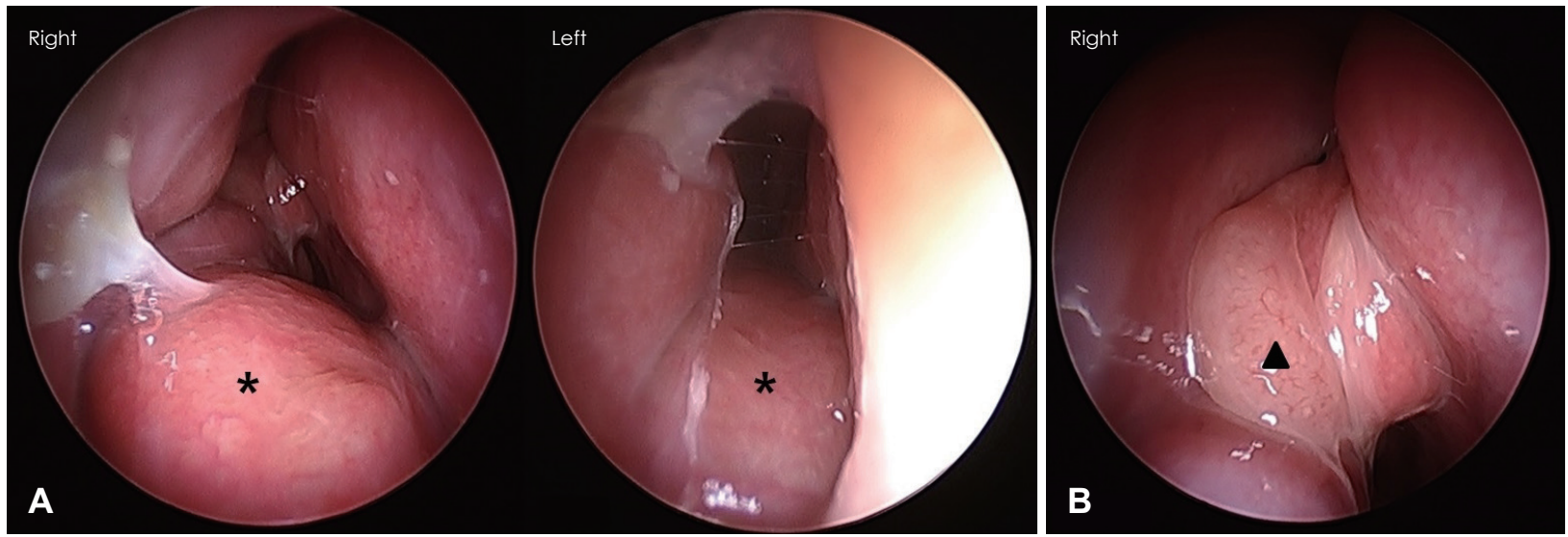

Fig. 1. Preoperative endoscopic findings. Both nasal floor bulging lesions $\left.{ }^{*}\right)$ by the nasopalatine duct cyst (A). Nasal polyp at right middle meatus (arrowhead) (B).
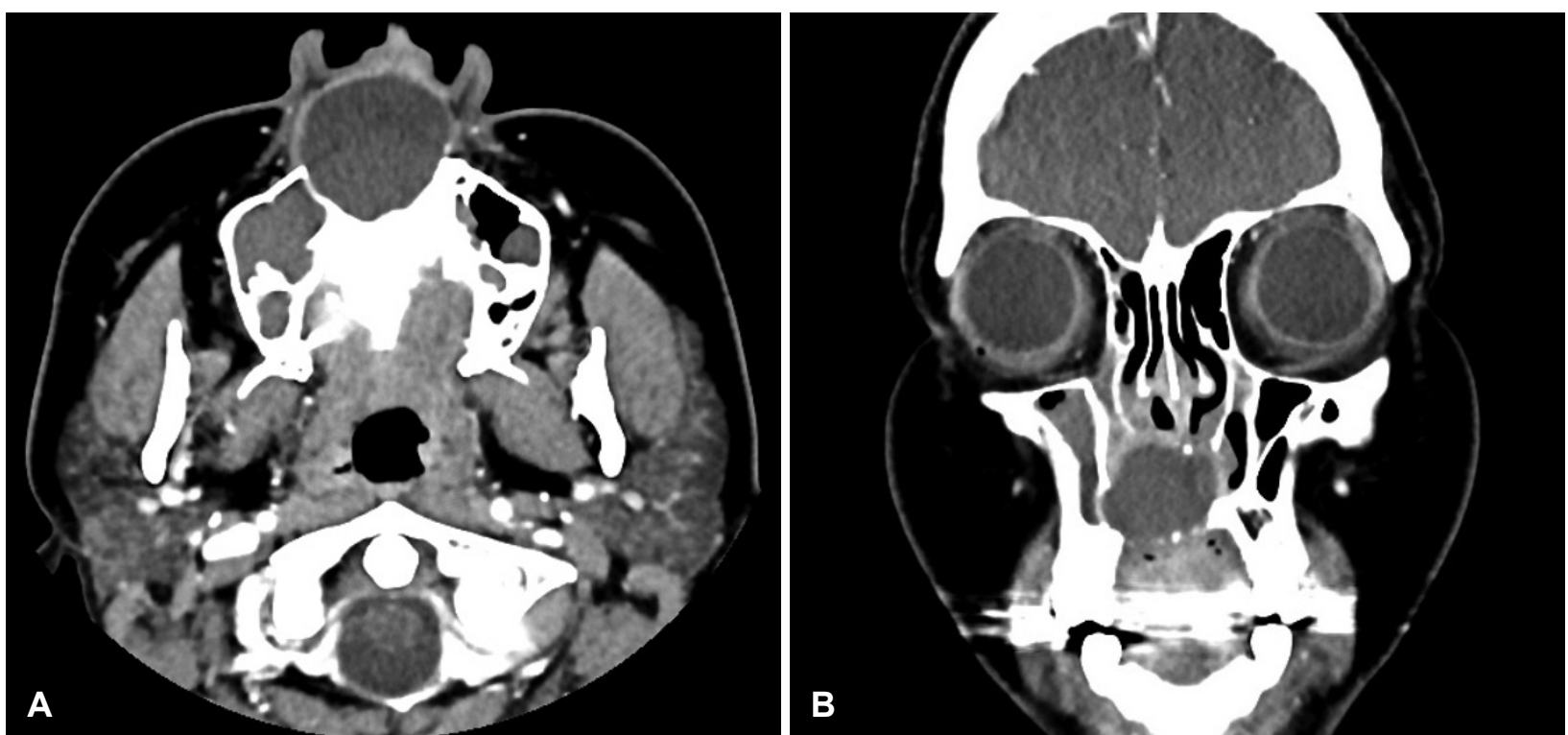

Fig. 2. Preoperative paranasal sinus CT findings. Axial view shows $3 \times 3 \times 2.5 \mathrm{~cm}$ sized cystic lesion with rim enhancement adjacent to the incisive canal (A). Coronal view shows soft tissue density at the right maxillary sinus and ethmoid sinus (B). 
떼내어 조직검사를 시행하였다. 뿐만 아니라 회전식 흡입기 (microdebrider)를 이용하여 절개부를 주변 정상 뼈조직까 지 넓게 제거하였고 이후 실라스틱판(silastic sheet)를 비강 저 부위에 고정하고 수술을 종료하였다.

환자는 수술하고 다음날 특별한 합병증 없이 퇴원하였고 외 래에서 경과 관찰하기로 하였다. 이후 우측 상악동에서 발견 된 조직의 병리 검사 결과는 콜레스테롤 육아종으로 진단 되 었으며, 낭성 종물의 조직은 만성 염증을 동반한 비구개관낭 으로 최종 진단 되었다(Fig. 3). 수술 전에 호소하던 코막힘과 비구순부위 압박감은 수술 직후 호전되었으며 수술 18 개월 후
외래에 내원하였을 때 비중격하단에서 천공이 관찰되었으나 비구개관낭의 재발이나 그 이외의 합병증 없이 조대술한 부위 의 상피화가 관찰되었다(Fig. 4).

\section{고 찰}

비구개관낭은 상악뼈에 발생하는 가장 흔한 비치성낭종으 로 이를 진단하는데 영상학적 검사는 중요한 역할을 한다. ${ }^{10)}$ 비구개관낭은 $\mathrm{CT}$ 영상에서 상악 중심부에 대칭적인 형태의 경계가 명확한 소견을 보이며 ${ }^{8)}$ 때로는 상악뼈 결손을 동반하
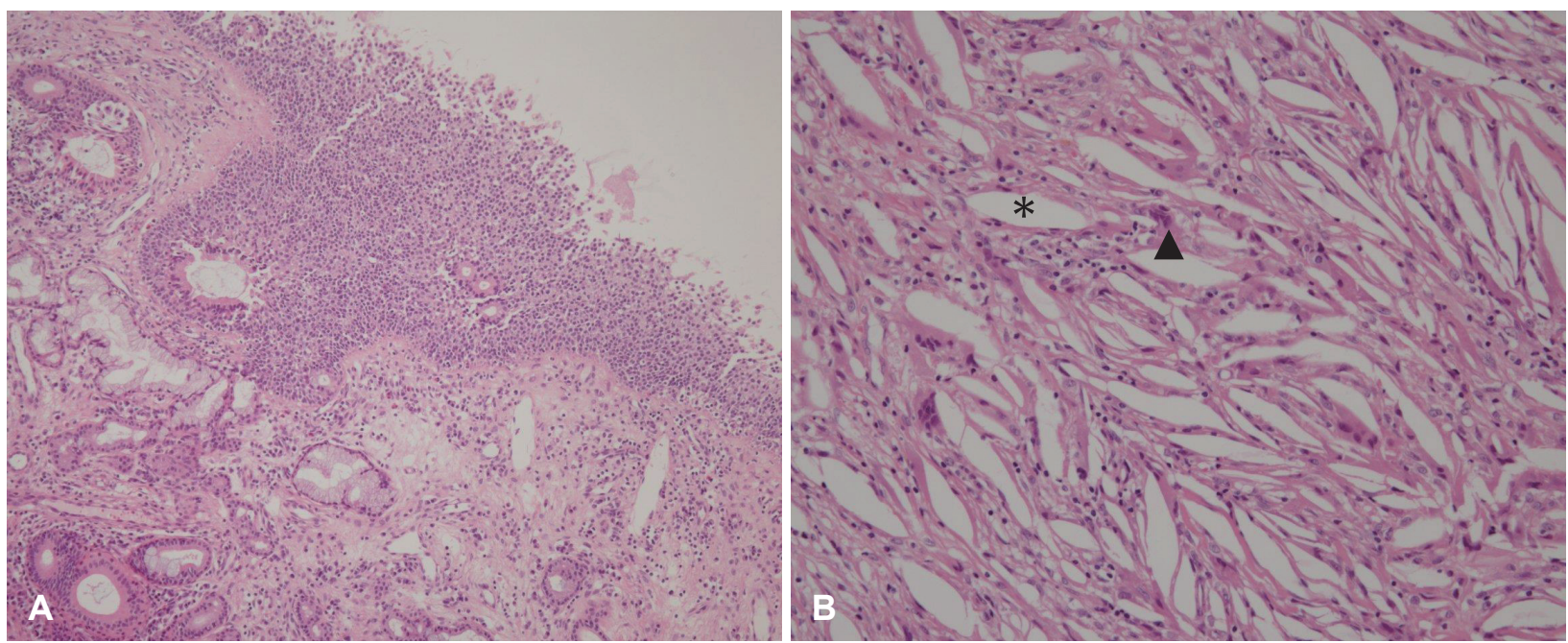

Fig. 3. Postooperative histopathologic findings. Ciliated pseudostratified columnar epithelium with chronic inflammation was shown in nasopalatine duct cyst wall $(\mathrm{H} \& \mathrm{E}, \times 100)(\mathrm{A})$. The granulomatous lesion is characterized by cholesterol clefts $\left.{ }^{*}\right)$ surrounded by multinycleated giant cells (arrowhead) $(\mathrm{H} \& \mathrm{E}, \times 200)(B)$. H\&E: hematoxylin and eosin.
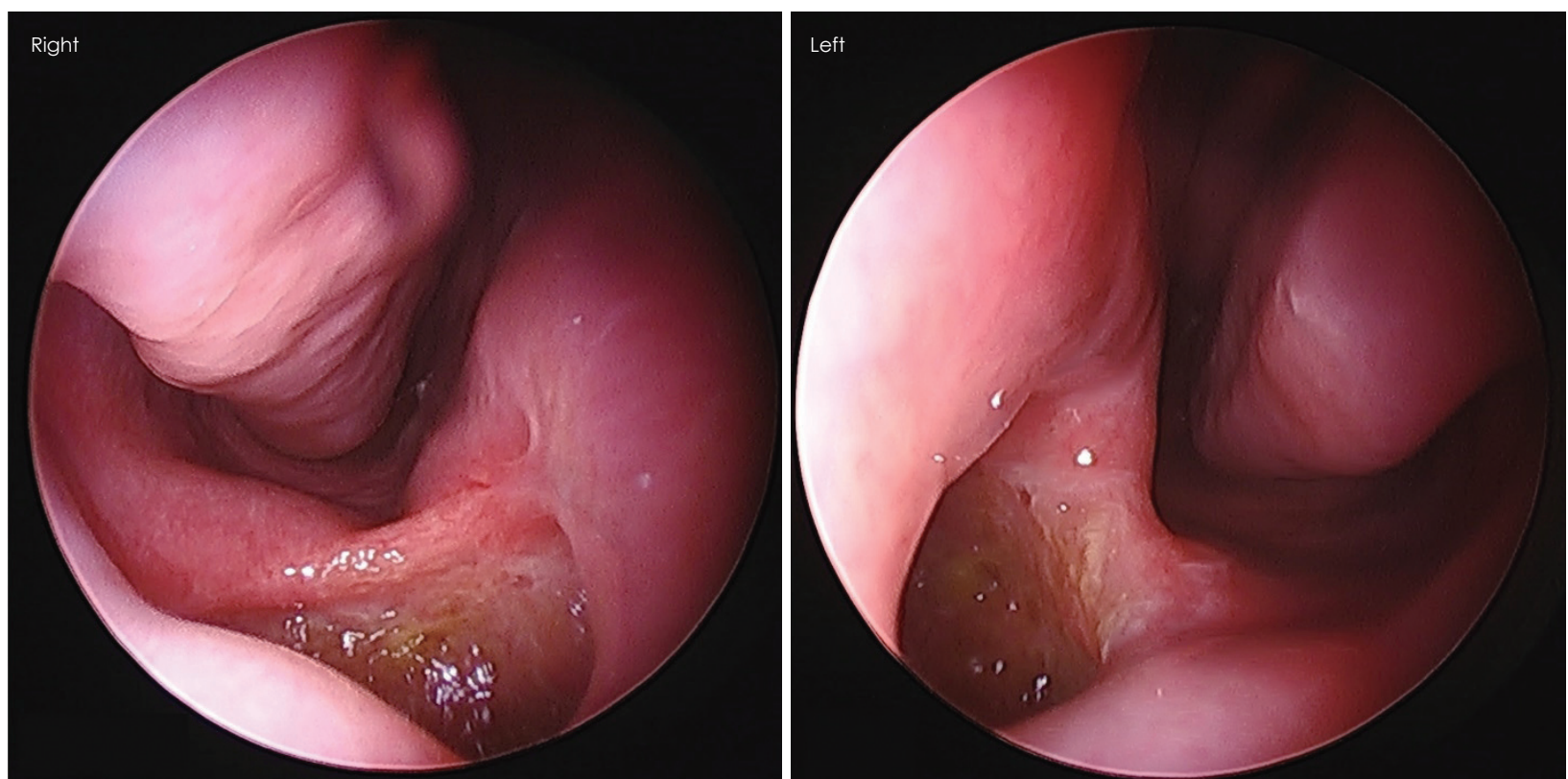

Fig. 4. Postoperative endoscopic findings. Both marsupializated sites were well epithelialized. 
기도 한다. ${ }^{10)}$ 이러한 영상학적 소견은 치근낭(periapical cyst), 비순낭종(nasolabial cyst) 등의 악안면에 발생하는 낭 종을 감별하는데 도움을 줄 수 있다. ${ }^{10)}$ 반면에 비부비동에 발 생하는 콜레스테롤 육아종은 CT 영상에서 경계가 명확한 연부조직 종물로 보인다. ${ }^{11)}$ 하지만 CT 영상만으로는 콜레스 테롤 육아종을 진단하기가 어렵기 때문에 자기공명영상 (Magnetic Resonance Image, MRI)이 감별진단에 도움이 된다. 콜레스테롤 육아종의 전형적인 MRI 소견은 $\mathrm{T} 1$ 강조영 상과 T2 강조영상에서 높은 신호 강도 소견을 보이며, 헤모 시데린(hemosiderin)의 영향으로 종물의 주변부가 T2 강조 영상에서 낮은 신호 강도 소견을 보이기도 한다.)

본 증례는 CT 영상에서 상악뼈의 낭종이 비록 우측으로 치우쳐 있지만 절치관의 소실과 경구개의 결손 및 대칭적인 낭종의 형태로 보여 비구개관낭에 합당한 소견을 보였다. 하 지만 수술 전 CT 영상을 통해 비용종을 동반한 만성 비부비 동염으로 예상한 본 증례처럼 비부비동에 발생하는 콜레스 테롤 육아종은 $\mathrm{CT}$ 영상만으로 진단을 하는 것이 어렵고 ${ }^{4)}$ 수술 중에 발견되는 종물에 대한 조직검사를 통해 최종 진 단을 할 수 있다. ${ }^{4}$

비구개관낭은 증상이 없더라도 이차적인 감염을 유발하여 상악뼈의 천공(fenestration)이나 누공(fistula)을 유발할 수
있고 드물지만 악성화된 보고도 있어 ${ }^{6}$ 구강접근(transoral approach) 혹은 구순하접근(sublabial approach)을 통한 전 적출술이 표준치료법으로 인식된다. ${ }^{6}$ 뿐만 아니라 내시경으 로 비강 내에서 낭종을 찾을 수 없을 정도로 작은 낭종의 경 우는 조대술 시행에 어려움이 있어 전적출술을 시행하는 것 이 좋다고 보고되었다. ${ }^{8)}$ 하지만 전적출술 시 발생하는 비구 강누공, 치아손실 등의 심각한 합병증과 경제적인 비용 및 수술 방법의 복잡함 등으로 인해 조대술을 시행하기도 한 다. ${ }^{8)}$ 비구개관낭에 대한 전적출술과 조대술의 치료 효과 및 합병증에 대한 대규모의 연구는 아직 보고된 바가 없었다. 하지만 비순낭종의 치료 방법을 비교한 Sheikh 등 ${ }^{12}$ 의 연구 에서 전적출술을 시행한 184 명과 조대술을 시행한 79 명을 비교하였을 때 두 수술법의 재발률에 대한 유의미한 차이는 없으나 전적출술의 경우는 $27.2 \%$ 에서 합병증이 발생하였고, 조대술을 시행한 경우에는 $13.9 \%$ 에서 합병증을 보였다. ${ }^{12)}$ 발 생한 합병증으로는 안면부종, 치통, 감각이상 등이 있었고 비 구강누공, 치아결손의 합병증이 전적출술을 시행한 환자에 서 1예씩 보고되었다. ${ }^{2)}$ 국내에서 보고된 비구개관낭에 대한 10 예의 문헌을 고찰해보았을 때 2 명의 환자를 제외한 대부 분의 환자는 조대술을 시행받았다(Table 1). 전적출술을 시 행 받은 한 명의 환자에서 결손 부위에 뼈이식을 시행하여

Table 1. Case reviews of nasopalatine duct cysts reported in Korea

\begin{tabular}{|c|c|c|c|c|c|c|c|c|c|}
\hline Author & Year & Sex & Age & Chief complaint & $\begin{array}{l}\text { Maximum } \\
\text { size }(\mathrm{mm})\end{array}$ & Treatment & $\begin{array}{c}F / U \\
\text { month }\end{array}$ & Complication & Recurrence \\
\hline Kim, et $\mathrm{al}^{5)}$ & 2005 & Female & 61 & Nasolabial swelling & 26 & $\begin{array}{l}\text { Enucleation with } \\
\text { bone chip graft }\end{array}$ & 6 & None & None \\
\hline Chung, et $\mathrm{al}^{6)}$ & 2008 & Male & 65 & Nasolabial pain & 60 & $\begin{array}{l}\text { Enucleation with } \\
\text { bone chip graft }\end{array}$ & 12 & $\begin{array}{l}\text { Inflamation } \\
\text { of bone graft }\end{array}$ & None \\
\hline Cinn, et $\mathrm{al}^{7)}$ & 2009 & Male & 40 & $\begin{array}{l}\text { Nasal obstruction, } \\
\text { hard palate swelling }\end{array}$ & 27 & $\begin{array}{l}\text { Endoscopic } \\
\text { marsupialization }\end{array}$ & 12 & None & None \\
\hline \multirow[t]{2}{*}{ Park, et $\mathrm{al}^{8)}$} & 2012 & Male & 49 & $\begin{array}{l}\text { Mucopurulent } \\
\text { rhinorrhea, swelling }\end{array}$ & 30 & $\begin{array}{l}\text { Endoscopic } \\
\text { marsupialization }\end{array}$ & 12 & None & None \\
\hline & & Male & 16 & $\begin{array}{l}\text { Incidental } \\
\text { nasopalatine mass }\end{array}$ & 27 & $\begin{array}{l}\text { Endoscopic } \\
\text { marsupialization }\end{array}$ & 10 & None & None \\
\hline \multirow[t]{5}{*}{ Hong, et $\mathrm{al}^{9)}$} & 2014 & Male & 39 & $\begin{array}{l}\text { Nasal obstruction, } \\
\text { perinasal swelling }\end{array}$ & 22 & $\begin{array}{l}\text { Endoscopic } \\
\text { marsupialization }\end{array}$ & 0.5 & $\begin{array}{l}\text { Perforated } \\
\text { inferior septum, }\end{array}$ & None \\
\hline & & Male & 29 & $\begin{array}{l}\text { Nasal obstruction, } \\
\text { perinasal swelling }\end{array}$ & 27 & $\begin{array}{l}\text { Endoscopic } \\
\text { marsupialization }\end{array}$ & 6 & crust & None \\
\hline & & Male & 19 & Perinasal swelling & 28 & $\begin{array}{l}\text { Endoscopic } \\
\text { marsupialization }\end{array}$ & 6 & & None \\
\hline & & Male & 41 & $\begin{array}{l}\text { Nasal obstruction, } \\
\text { perinasal swelling }\end{array}$ & 31 & $\begin{array}{l}\text { Endoscopic } \\
\text { marsupialization }\end{array}$ & 4 & & None \\
\hline & & Male & 33 & Nasal obstruction & 28 & $\begin{array}{l}\text { Endoscopic } \\
\text { marsupialization }\end{array}$ & 2 & & None \\
\hline Present, case & 2019 & Female & 30 & $\begin{array}{c}\text { Nasolabial swelling, } \\
\text { nasal obstruction }\end{array}$ & 30 & $\begin{array}{l}\text { Endoscopic } \\
\text { marsupialization }\end{array}$ & 18 & $\begin{array}{l}\text { Perforated } \\
\text { inferior septum }\end{array}$ & None \\
\hline
\end{tabular}


감염된 경우가 1 예 있었고 조대술을 시행 받은 환자에서는 비중격하단에 천공이 발생하는 소견이 있었다. 그럼에도 불 구하고 비구개관낭을 조대술한 경우 결손 부위의 상피화를 관찰할 수 있었으며 재발이나 합병증은 관찰되지 않았다. 본 증례도 기존의 치료와 유사하게 비구개관낭에 대해 조대술 을 시행하여 비중격하단의 천공 이외 특별한 합병증과 재발 없이 치료를 마무리하였다.

본 증례는 비구개관낭이 콜레스테롤 육아종의 발생 과정 에서 미치는 상호 관련성을 설명하기에는 제한점이 있다. 하 지만 비부비동에 발생하는 콜레스테롤 육아종이 자연공의 폐쇄 후 만성적인 염증으로 불충분한 환기가 이루어지는 부 위에 출혈이 동반되어 발생되었다고 제시되었다.) 이와 유사 하게 본 증례도 비용종에 의한 상악동의 자연공 폐쇄로 인 한 만성 비부비동염에서 비구개관낭 주변부에 빼의 재형성 과정으로 상악동에 출혈이 발생하여 콜레스테롤 육아종을 유발하였을 것으로 추정한다. 다만 본 증례와 같은 보고가 없으므로 두 질환의 관련성에 대해서는 추가적인 연구가 필 요할 것으로 생각된다.

\section{Acknowledgments}

None.

\section{Author Contribution}

Conceptualization: Ju Chang Kang. Data curation: Ju Chang Kang, Sang Hyeon Ahn. Formal analysis: Kyu Ha Shin. Investigation: Ju Chang Kang, Kyu Ha Shin. Project administration: Sang Hyeon Ahn. Supervision: Sang Hyeon Ahn. Visualization: Kyu Ha Shin, Eun Mee Han. Writing — original draft: Ju Chang Kang. Writing — review \& editing: Kyu Ha Shin, Eun Mee Han, Sang Hyeon Ahn.

\section{ORCID}

Sang Hyeon Ahn https://orcid.org/0000-0002-2389-0005

\section{REFERENCES}

1) Swanson KS, Kaugars GE, Gunsolley JC. Nasopalatine duct cyst: An analysis of 334 cases. J Oral Maxillofac Surg 1991;49(3):268-71.

2) Escoda Francolí J, Almendros Marqués N, Berini Aytés L, Gay Escoda C. Nasopalatine duct cyst: Report of 22 cases and review of the literature. Med Oral Patol Oral Cir Bucal 2008;13(7):E438-43.

3) Leon ME, Chavez C, Fyfe B, Nagorsky MJ, Garcia FU. Cholesterol granuloma of the maxillary sinus. Arch Pathol Lab Med 2002; 126(2):217-9.

4) Han BH, Choi IS. A case of cholesterol granuloma of maxillary sinus misdiagnosed as odontogenic cyst. J Rhinol 2018;25(2):108-13.

5) Kim YJ, Seo JW, Jun YJ, Kim SS. A clinical experience of nasopalatine duct cyst with bony defect. J Korean Soc Plast Reconstr Surg 2005;32(2):255-8.

6) Chung J, Park SY, Son WR, Kim JM. A case of huge nasopalatine duct cyst with infection. Korean J Otorhinolaryngol-Head Neck Surg 2008;51(10):946-9.

7) Cinn YG, Park MK, Kang HJ, Lee HM. A case of endoscopic marsupialization of a nasopalatine duct cyst. J Rinol 2009;16(2):152-4.

8) Park CH, Lee JW, Lee JH, Hong SM. Two cases of Marsupialization of nasopalatine duct cyst. Korean J Otorhinolaryngol-Head Neck Surg 2012;55(4):239-42.

9) Hong SD, Kim JH, Choi JE, Chung SK. Endoscopic endonasal marsupialization of extensive nasopalatine duct cysts protruding into Nasal Cavity. J Rhinol 2014;21(1):28-30.

10) Pevsner PH, Bast WG, Lumerman H, Pivawer G. CT analysis of a complicated nasopalatine duct cyst. N Y State Dent J 2000;66(6):18-20.

11) Lee IH, Nam IC, Jeong JW, Kim DH. A case of cholesterol granuloma in the nasal septum. Korean J Otorhinolaryngol-Head Neck Surg 2016;59(1):49-52.

12) Sheikh AB, Chin OY, Fang CH, Liu JK, Baredes S, Eloy JA. Nasolabial cysts: A systematic review of 311 cases. Laryngoscope 2016;126(1):60-6. 